\title{
Wide Aquinas research - channelled too narrowly?
}

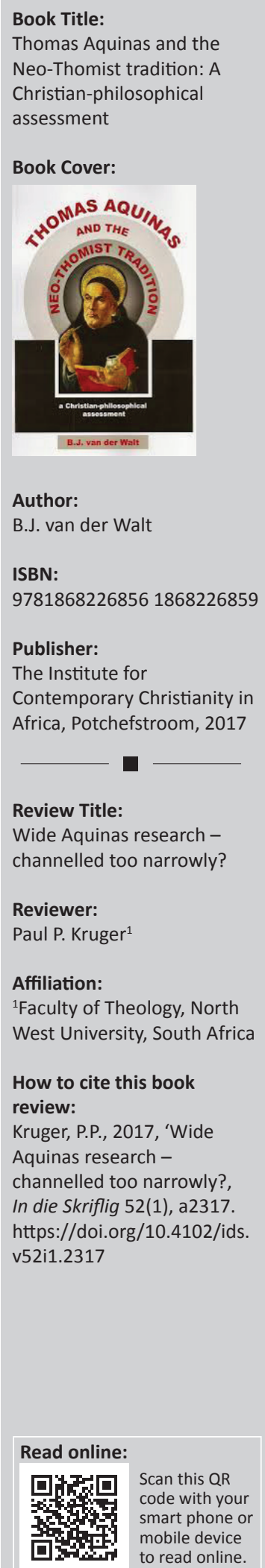

With his characteristic humility the author of this book calls himself 'a mere philosophical dwarf' who 'dared to criticize a giant in the history of Western thought' (p. 158). Yet, referring to the wellknown adagium attributed to Bernard of Chartres, that we are 'as dwarfs standing on the shoulders of giants', the Italian intellectual, Umberto Eco, insightfully comments that even Thomas Aquinas once was a dwarf standing on gigantic shoulders (like those of Augustine and Aristotle). In the same vein it might be said that the 'dwarf' has grown out to be a giant in contemporary African and other philosophies. Having, admittedly, only read a fraction of his massive philosophical and theological output, but, nevertheless, having known the author since we were fellow students in the first-year philosophy class, I would venture to describe this present publication as an instance of mature culmination, resulting from many years of multifaceted, pioneering, scholarly and passionate work. In all the various facets of the author's work - academic, pastoral, organisational and more - he was blessed by the Lord with a very creative and dynamic driving force (always supported splendidly by his wife). This book again witnesses to his painstaking, conscientious and scholarly-specialist approach. (It speaks volumes that he had read Aquinas anew in the original Latin as he was preparing for the present work!) Furthermore, one can truly appreciate that the passionate heart - which is so central in the kind of philosophy he espouses - informs his whole person and work as Christian.

The book under consideration consists of eight chapters. In the initial five chapters a lucid and synoptic view of certain mainlines in Aquinas's oeuvre is presented, namely its fundamental 'religious direction'; its law-idea where van der Walt finds the key for unlocking Aquinas' philosophy as a whole; its ontological view of God and reality; its anthropological and epistemological manifestations; and its conception of providence wherein the author finds a kind of illustrative summary of Aquinas's thinking on the relation between God and man. Chapter six is titled: 'Christianising Hellenism implies the Hellenisation of Christian faith'. This section (together with chapter eight) seems to be crucial for understanding the author's own deep convictions, as well as his concomitant methodological choices, regarding his philosophical - and, it might probably be added, theological - thought. The last two chapters deal with the history of 'seven centuries of Neo-Thomist thinking' and its evaluation from a problem-historical methodological vantage point. Appreciation must be expressed for the thoughtful structuring and reader-friendly presentation of this publication. 'In der Beschränkung zeigt sich der Meister' [In the limitation the master is shown] - this quotation which I heard from our first teacher in the history of philosophy, Dr Jan Taljaard, is indeed applicable to this book! A few critical remarks, however, are necessary.

Firstly, the 'consistent problem-historical method' (pp. 138-152, 178-181) merits attention. Throughout the book, but especially in chapters 6 and 8, the author's preference and broad adherence to Vollenhoven's anti-synthetical thinking (p. 132) and corresponding problemhistorical classification of the history of philosophy is palpable. He admits a 'correspondence with the Reformational approach in general' (p. 137) as he found it in the philosophical initiatives of Vollenhoven, Dooyeweerd and their followers. Thinking further along this trajectory he seems to be seeking a kind of anti-synthesis approach that is sensitive to 'relative continuity between Gospel and culture' as well as to 'radical discontinuity'. The 'red lights' only begin to flash 'where relative continuity is no longer relative, so that the radical discontinuity no longer prevails' (pp. 136, 137). The question arises whether it cannot legitimately be argued that a philosophy striving after radical continuity with the gospel (as sought in Reformational philosophies) is itself not accompanied - as its shadow-side - by a relative discontinuity with the Bible. This perspective, to my mind, should be given much sharper relief than it receives in the present discourse - if it is there at all. Luther's 'simul iustus et peccator' [simultaneously just and sinner] should resonate through any 'unmasking' of radical discontinuity with Scripture. This paradox remains, especially

Copyright: (C 2018. The Authors. Licensee: AOSIS. This work is licensed under the Creative Commons Attribution License. 
when the eschatological 'ambivalence' of all our thinking inhabits our formulations. Long ago a reformed poet (Rijnsdorp) surmised that this 'evangelical ambivalence' was direly missing in many reformed 'epigones' of the postKuyper era in the Netherlands. Satirically he describes this ambivalence-negating thinking as follows: 'just create this beautiful and correct formulation, and you have rest, you can relax, because you have summarized the (threatening philosophical) situation so pointedly in a few words'! A puny little 'labels-war' then rages! With all respect, are there not remnants of this anti-ambivalence 'war' present in our author's anti-synthesis 'fixation'?

Secondly, to contend that the 'real meaning of Sola Scriptura' lies in 'looking at reality in the light of the Bible' - as the author with good reason maintains (p. 144) - has disruptive consequences for any attempt at systematically 'boxing in' synthetic thinkers in 'types 'and 'schools'. Granted, such minute classifications might serve good pedagogy which is, of course, also necessary. Yet, I was deeply struck by the Bible-word (1 Cor 4:15) which - mirabile dictu - Harnack attached epigraphically to book one of his great History of dogma - which the author correctly hails as a landmark of 'dehellinisation' in Christian thinking: 'Even though you have ten thousand guardians (Gk. paedagogous) in Christ, you do not have many fathers, for in Christ Jesus I became your father through the gospel'. Amongst the things Paul had named previously and which contributed to his becoming a 'father in Christ' is his insistence (against the futile thinking of the worldly wise) that for Christians 'all things are yours, whether Paul or Apollos or Cephas or the world or life or death or the present or the future - all are yours, and you are of Christ and Christ is of God' (1 Cor 3:21-23). Looking to the history of philosophy in the light of the Bible should thus lead a Christian philosopher away from 'infancy in Christ' (cf. 1 Cor 3:1) towards a spiritual maturity that can courageously appropriate Aristotle, Thomas, Nietzsche, et cetera as belonging to us, because we belong to Christ. This might open up something of our 'only comfort' (HC 1:1) for philosophy - and simultaneously counter the seemingly pervasive fear of constantly being overwhelmed by syntheticism. In this regard I indeed can have sympathy with the approach of Klapwijk - in his reference to the two sides of 2 Corinthians 10:5 (p. 131).

Thirdly, a sense of urgency vis-à-vis cleansing our thinking of synthetic traces pervades the book. It is as if this urgency reaches a crescendo on the second last page of the discourse:
There is a good reason for the statement that even Reformed theologians and church members in general up to the present day have not succeeded in cleansing themselves completely from the blemish of some or other [sic] natural-supernatural dualism.

This 'statement' should undoubtedly be heeded! Nevertheless, the alternative that the author proposes is not the only option for tackling this problem. Besides, the compulsion for an evergreater purity of Christian thinking and Christian churches frequently produces side effects of which we as Reformed churches have many wounds left unto this day. Recently the well-known theologian Leithart showed how a philosophical 'rave' for systems in order to 'gain control over everything, getting everything in its rank' seems to take its cue from fleshly forms of purification (cf. the Pharisees' obsession with purity). 'To stave off the dangers of intellectual and cultural disorders', Leithart argues, thinkers often employ 'separations that resemble the holiness and purity separations of stoicheic (fleshly) order'. Philosophy in step with the Spirit (cf. Gal 5:25) is, however, always aware that it is still engaged in a warfare with the 'elements of the world' (Col2:8)-despite the encouragement that 'what the Spirit desires' is already victorious (cf. Gal 5:16, 17). What appears to me to be the greatest hiatus in the alternative to synthetic thinking that van der Walt probes (pp. 196,197 ) is exactly this pneumatological emphasis. Philosophy in step with the Spirit proves to be 'untroubled by untied threads and undotted $I^{\prime} s^{\prime}$... Pneumatological thinkers - of course, in the light of the gospel - 'would be impure thinkers' (Leithart).

Lastly, the question is to be asked whether the way the author sometimes critiques philosophers who he suspects of (veering towards) synthetic thinking displays the required scientific nuancing and fairness. Glaring examples of this critique seem to be present in his treatment of 'Radical Orthodoxy', as well as of the perspective of 'transcendence in immanence' that a recent doctoral thesis explores (cf. pp. $5,103)$. The dissertation in question, far from gravitating towards synthetic thinking, states in its 'Conclusion' that 'the notion of transcendence in immanence, as distinguished into temporal and theological immanence, may be a very useful instrument' for a Christian theology. A certain continuity as well as a definite 'parting of ways' with a contemporary non-Christian philosophy are clearly articulated. In my estimation van der Walt's critique in this instance entails an eisegesis, stemming from his preconceived antisynthetic pathos.

In conclusion, I heartily recommend this book. Reading and studying it will be richly rewarding! 